REKOGNISI: Jurnal Pendidikan dan Kependidikan

ISSN 2527-5259 Vol.1 No.1 Desember 2016

\title{
PENGGUNAAN MEDIA GAMBAR UNTUK MENINGKATKAN HASIL BELAJAR IPS SISWA
}

\author{
Dahniar Harahap \\ PGSD Universitas Nahdlatul Ulama Sumatera Utara \\ Email :Niar.Harahap2o@gmail.com
}

\begin{abstract}
ABSTRAK
Tujuan penelitian ini adalah : (a) untuk mengetahui bagaimana penggunaan media gambar dalam meningkatkan hasil belajar siswa pada pembelajaran IPS dengan materi keragaman suku bangsa dan budaya di Indonesia (b) untuk mengetahui hasil belajar siswa pada mata pelajaran IPS materi keragaman suku bangsa dan budaya di Indonesia dengan menggunakan media gambar. Media yang digunakan dalam penelitian ini adalah media gambar, yaitu berupa gambar dari keragaman suku bangsa dan budaya yang ada di Indonesia, seperti gambar rumah adat, pakaian adat, senjata tradisional dan tarian tradisional dari setiap daerah yang ada di Indonesia. Tes dilakukan sebanyak tiga kali yaitu test awal (pretest), test hasil belajar siklus I dan siklus II. Berdasarkan analisis data, yaitu menunjukkan bahwa: (1) kesulitan yang dihadapi siswa dalam pembelajaran IPS yaitu: siswa yang belum mampu menjelaskan isi gambar karena kurang memiliki rasa percaya diri maju didepan kelas dan menjelaskan isi gambar kepada teman, (2) cara penggunaan media gambar dalam pembelajaran IPS pada siklus I yaitu, guru menjelaskan materi keragaman suku bangsa dan budaya yang ada di Indonesia dengan menggunakan gambar, lalu guru meminta siswa untuk mengomentari gambar, dan siklus II guru menyuruh siswa untuk membentuk kelompok dan mengerjakan tugas yang diberikan guru secara kelompok dan memberikan latihan individu, (3) pada tes awal (pretest) kemampuan siswa dalam menyelesaikan materi keragaman suku bangsa dan budaya yang ada di Indonesia adalah rendah. Pada test hasil belajar I dari 37 orang siswa yang mengikuti test, terdapat 18 orang siswa atau 48,64\% yang tuntas belajar dan yang tidak tuntas belajar sebanyak 19 siswa atau 51,36\%. Pada hasil belajar siklus II, dari 37 siswa yang mengikuti test terdapat 35 siswa atau 94,60\% yang tuntas belajar, dan ada 2 siswa atau 5,40\%
\end{abstract}


yang tidak tuntas belajar. Dapat disimpulkan bahwa penggunaan media gambar dapat meningkatkan hasil belajar siswa.

Kata kunci: media gambar, hasil belajar, ilmu pengetahuan sosial

\begin{abstract}
The purpose of this study are: (a) to know how to use the media image in improving student learning outcomes in social studies learning the material diversity of tribes and cultures in Indonesia (b) to determine student learning outcomes in social studies material diversity of tribes and cultures Indonesia using media images. Media used in this study is the media image, ie an image of the diversity of tribes and cultures in Indonesia, such as image custom homes, traditional clothing, traditional weapons and traditional dances from all regions in Indonesia. The test is performed three times the initial test (pretest), test results of studying the first cycle and the second cycle. Based on data analysis, which showed that: (1) difficulties faced by students in social studies learning are: students who have not been able to explain the contents of the image due to lack of confidence developed in the classroom and explain the contents of the image to a friend, (2) how to use media images in learning social studies in the first cycle that, the teacher explains the material diversity of tribes and cultures in Indonesia by using an image, then the teacher asked students to comment on the pictures, and the second cycle the teacher asks the students to form groups and work the assignment of teachers in groups and provide individual training. (3) At the beginning of the test (pre-test) the ability of the student in completing the material diversity of tribes and cultures in Indonesia is low. I learned on the test results of 37 students who take the test, there are 18 students or $48.64 \%$ were thoroughly studied and are not thoroughly studied as many as 19 students or $51.36 \%$. In the second cycle of learning outcomes, from 37 students who take the test are 35 students or $94.60 \%$ were thoroughly studied, and there are 2 students or $5.40 \%$ were not thoroughly studied. It can be concluded that the use of media images can improve student learning outcomes.
\end{abstract}

Key words: media images, learning outcomes, social sciences

\title{
PENDAHULUAN
}

Guru merupakan faktor yang turut mempengaruhi proses belajar mengajar, hendaknya mampu menggunakan alat-alat yang tersedia. Guru dituntut untuk dapat mengembangkan keterampilan membuat media yang sesuai dengan keadaan siswa agar siswa dapat meningkatkan hasil belajar pada pelajaran IPS dengan menggunakan media.

Upaya untuk meningkatkan kualitas pendidikan menjadi tugas dan tanggung jawab guru. Gurulah yang langsung membina para siswa di sekolah melalui proses kegiatan belajar mengajar, namun mengupayakan peningkatan kualitas pendidikan ini bukanlah hal yang mudah. Untuk mendapatkan hasil yang optimal dalam proses pembelajaran di kelas perlu diperhatikan dua kompenen utama, yaitu metode mengajar dan media pengajaran, itulah sebabnya dalam hal ini proses dan hasil belajar para siswa 
menumbuhkan perbedaan yang sangat berarti antara pengajaran tanpa media dengan pengajaran yang menggunakan media. Fungsi media dalam proses pembelajaran adalah untuk meningkatkan rangsangan peserta didik dalam kegiatan belajar. Berbagai media pembelajaran, gambar adalah media paling umum dipakai. Dia merupakan bahasa yang umum, yang dapat dimengerti dan dinikmati di mana-mana. Gambar ilustrasi fotografi adalah gambar yang tidak dapat diproyeksikan, dapat dipergunakan, baik dalam lingkungan anak-anak maupun dalam lingkungan orang dewasa. Gambar yang berwarna umumnya menarik perhatian. Semua gambar mempunyai arti, uraian dan tafsiran sendiri. Media gambar adalah media yang dapat memperlancar pemahaman dan memperkuat ingatan siswa. Oleh karena itu, gambar dapat dipergunakan sebagai media pendidikan dan mempunyai nilai-nilai pendidikan bagi peserta didik yang memungkinkan belajar secara efisien peserta didik yang berkaitan dengan pemanfaatan media gambar.

Hasil pengamatan yang dilakukan peneliti di MIN Medan Petisah dapat diketahui bahwa, yang menjadi permasalahannya adalah pada umumnya guru bidang studi IPS masih bersifat konvensional, artinya aktivitas pembelajaran hanya berpusat pada guru yang hanya menggunakan metode ceramah yang berfokus pada buku teks pelajaran IPS dan kurang dalam menggunakan media.Tentu hal ini sangat berpengaruh terhadap hasil belajar siswa, karena dalam proses pembelajaran membuat siswa sulit memahami konsep materi yang diberikan oleh guru, sehingga siswa kurang menyukai pelajaran IPS karena dianggap membosankan. Hal tersebut berdampak pada kemampuan siswa dalam menyelesaikan soal-soal dengan bentuk pilihan berganda dari seluruh siswa kelas V hanya $48 \%$ saja yang dapat menyelesaikan soal-soal pembelajaran IPS dengan baik dan benar. Padahal yang dituntut dalam materi IPS ini, anak dapat mengetahui berbagai keragaman suku bangsa dan budaya yang ada di Indonesia. Hal ini dikarenakan rendahnya penguasaan materi yang dipahami siswa. Agar proses belajar mengajar berjalan dengan baik dan efektif, diperlukan usaha yang sungguh-sungguh dari semua pihak, khususnya guru. Media merupakan salah satu alat yang dapat dijadikan penentu keberhasilan tersebut dan memudahkan guru dalam proses pembelajaran. Media juga bisa membuat proses pembelajaran lebih menarik dan dapat mengurangi kesulitan yang dialami oleh siswa dalam memahami pelajaran yang diberikan oleh guru. Karena fungsi media dalam proses pembelajaran yaitu untuk meningkatkan rangsangan peserta didik dalam kegiatan belajar.

Penggunaan media gambar diharapkan membuat siswa lebih cepat memahami dan mengerti materi pelajaran sehingga dapat meningkatkan hasil belajar siswa pada mata pelajaran IPS, dan mampu mengaktifkan siswa dalam proses pembelajaran, sehingga suasana belajar lebih menarik dan menyenangkan.

Dalam Kamus Ilmiah Populer (Ramadhan, 2010: 276), media berarti perantara (informasi). Rossi dan Breidle mengemukakan bahwa media pembelajaran adalah seluruh alat dan bahan yang dapat dipakai untuk mencapai tujuan pendidikan seperti radio, televisi, buku, koran, majalah, dan sebagainya. Menurut Arsyad (2011: 3) media dalam proses belajar mengajar cenderung diartikan sebagai alat-alat grafis, photografis, 
atau elektronis untuk menangkap, memproses, dan menyusun kembali informasi visual atau verbal.

Dewasa ini gambar fotografi secara luas dapat diperoleh dari berbagai sumber, misanya dari surat-surat kabar, majalah-majalah, brosur-brosur dan buku-buku. Gambar, lukisan, kartun, ilustrasi dan foto yang diperoleh dari berbagai sumber tersebut dapat dipergunakan oleh guru secara efektif dalam kegiatan belajar mengajar.

Media gambar adalah perwujudan lambang dari hasil peniruan-peniruan benda, pemandangan, curahan pikiran, atau ide-ide yang divisualisasikan ke dalam bentuk dua dimensi, bentuknya dapat berupa gambar situasi dan lukisan yang berhubungan dengan pokok bahasan.

Rumusan penelitian ini adalah: (1) bagaimana penggunaan media gambar dalam meningkatkan hasil belajar siswa pada pembelajaran IPS dengan materi keragaman suku bangsa dan budaya di Indonesia, (2) hasil belajar siswa pada mata pelajaran IPS materi keragaman suku bangsa dan budaya di Indonesia dengan menggunakan media gambar. Tujuan penelitian ini adalah: (1) untuk mengetahui bagaimana penggunaan media gambar dalam meningkatkan hasil belajar siswa pada pembelajaran IPS dengan materi keragaman suku bangsa dan budaya di Indonesia, (2) untuk mengetahui hasil belajar siswa pada mata pelajaran IPS materi keragaman suku bangsa dan budaya di Indonesia dengan menggunakan media gambar.

\section{METODE PENELITIAN}

Penelitian ini bermaksud mengungkapkan suatu upaya memperbaiki proses pembelajaran dengan menggunakan media gambar pada mata pelajaran IPS di kelas V MIN Medan Petisah, maka penggunaan pendekatan Penelitian Tindakan Kelas (PTK) dipandang relevan dalam penelitian ini.

Menurut Suharsimi (dalam Asrori, 2001: 5) Penelitian Tindakan kelas terdiri dari tiga kata, yaitu "penelitian", "tindakan", dan "kelas". Penelitian adalah kegiatan mencermati suatu objek dengan menggunakan aturan metodologi tertentu untuk memperoleh data atau informasi yang bermanfaat untuk meningkatkan mutu suatu hal menarik minat dan penting bagi peneliti. Tindakan adalah suatu gerak kegiatan yang sengaja dilakukan dengan tujuan tertentu, yang dalam penelitian berbentuk rangkaian siklus kegiatan. Kelas adalah sekelompok siswa yang dalam waktu yang sama menerima pelajaran yang sama oleh guru.

Penelitian ini dilakukan di MIN Medan Petisah dengan subjek penelitian, siswa kelas V sebanyak 37 orang pada tahun pelajaran 2011/2012. Penelitian ini dilaksanakan dalam dua tahap yaitu tahap pratindakan dan tindakan. Tahap tindakan ada dua siklus, siklus I dan siklus II. Tiap siklus terdiri atas tahap perencanaan, tindakan, observasi, refleksi.

Pengambilan data dilakukan dengan teknik tes dan nontes. Tes berbentuk pilihan ganda, sehingga penskorannya, salah diberi skor 0 dan benar diberi skor 1 . Tes untuk 
mengetahui seberapa besar tingkat keberhasilan dari tindakan yang telah dilakukan, tingkat keberhasilan ditentukan dengan melihat dari kriteria yang telah ditetapkan yaitu:

$\leq 65=$ siswa tidak tuntas

$\geq 65$ = siswa tuntas belajar

Nontes berupa lembar observasi. Pengamatan dilakukan terhadap seluruh kegiatan pembelajaran melalui media gambar dan perubahan yang terjadi pada saat dilakukannya penyajian materi.

Analisis ini dilakukan dengan menggunakan persentase dan kuantitas data. Analisis ini dilakukan dengan mengetahui nilai rata-rata siswa dengan menggunakan persentase berikut:

$$
X=\frac{\sum X}{\sum N}
$$

Dimana : $x$ : nilai rata-rata

$\sum \mathrm{x}$ : jumlah semua nilai siswa

$\sum \mathrm{N}$ : jumlah seluruh siswa

Data kesalahan siswa yang telah direduksi kemudian disajikan dalam paparan data kesalahan jawaban siswa. Proses verifikasi dalam hal ini adalah tinjauan ulang terhadap catatan lapangan, memperbaiki pembelajaran dengan menafsirkan dan membuat kesimpulan tindakan-tindakan yang akan dilakukan untuk memperbaiki kesalahan jawaban siswa dalam penyelesaian soal pelajaran IPS.

1) Menarik Kesimpulan

Dalam kegiatan ini ditarik kesimpulan berdasarkan hasil penelitian yang telah dilakukan. Kesimpulan yang diambil merupakan dasar bagi pelaksanaan siklus berikutnya.

Berdasarkan kriteria ketuntasan hasil belajar menurut DIKNAS terdapat kriteria ketuntasan belajar perorangan dan klasikal, yaitu :

a. Seorang siswa dikatakan telah tuntas belajar jika siswa telah mencapai skor $65 \%$. Ketuntasan tersebut dihitung dengan rumus :

$D S=\frac{S y \times 100 \%}{S \text { maks }}$

Di mana :

$D S$ : daya serap

Sy: skor yang diperoleh

Smaks: skor maksimal

Dengan kriteria :

$D S<65 \%=$ siswa belum tuntas dalam belajar

$D S>65 \%=$ siswa tuntas dalam belajar

b. Suatu kelas dikatakan tuntas belajar jika kelas tersebut terdapat $65 \%$ siswa yang mencapai daya serap DS $>65 \%$. Ketuntasan tersebut dihitung dengan rumus : 


$$
D=\frac{x \times 100 \%}{n}
$$

Dimana :

$D$ : persentase ketuntasan kelas

$x$ : jumlah siswa yang telah tuntas belajar

$n:$ jumlah seluruh siswa.

\section{HASIL DAN PEMBAHASAN}

\section{Siklus I}

Berdasarkan hasil observasi terhadap aktivitas siswa yang dilakukan selama proses belajar pada siklus I memiliki 3 kategori yaitu, baik, cukup, dan kurang. Hasil observasi tersebut dapat dilihat pada tabel 1.

Tabel 1. Deskripsi Aktivitas Siswa Siklus I

\begin{tabular}{|c|l|c|}
\hline No & \multicolumn{1}{|c|}{ Aktivitas Siswa } & Kategori \\
\hline 1 & Berpartisipasi dalam pembelajaran & Baik \\
\hline 2 & Keseriusan siswa mengikuti pelajaran & Kurang \\
\hline 3 & Suasana kelas pada saat PBM & Cukup \\
\hline 4 & Keaktifan siswa dalam bertanya & Cukup \\
\hline 5 & Mendengar dan memperhatikan guru & Cukup \\
\hline 6 & Interaksi antara siswa & Kurang \\
\hline
\end{tabular}

Tiap kategori memiliki poin-poin masing-masing. 6 komponen aktivitas siswa yang tertera dalam lembar observasi: 1 poin untuk kategori baik, 3 poin kategori cukup, dan 2 poin untuk kategori kurang. Jadi dapat disimpulkan aktivitas siswa selama proses kegiatan pembelajaran sudah baik namun masih belum maksimal, terlihat kurangnya keseriusan siswa dalam mengikuti pembelajaran juga masih kurang dan suasana kelas juga belum kondusif. Interaksi antar siswa juga masih kurang. Sehingga diperlukannya cara-cara untuk lebih meningkatkan keaktifan siswa, dengan mengkolaborasikan penggunaan media gambar dengan metode-metode yang lebih menarik.

Pada akhir siklus diberikan tes akhir pada siklus I, dianggap berhasil apabila siswa mendapat nilai $\geq 65$. Persentase ketuntasan hasil belajar siswa pada test akhir I dapat dilihat pada tabel 2 dan tabel 3 .

\section{Tabel 2. Pengelompokan Ketuntasan Hasil Belajar Siswa Siklus I}

\begin{tabular}{|l|c|c|}
\hline \multicolumn{1}{|c|}{ Kategori } & f & \% \\
\hline Tuntas & 18 & 51 \\
\hline Tidak tuntas & 19 & 49 \\
\hline Jumlah & 37 & 100 \\
\hline
\end{tabular}




\section{Tabel 3. Persentase dan Pengelompokan Tingkat Hasil Belajar Siswa Siklus I}

\begin{tabular}{|l|c|c|c|}
\hline $\begin{array}{c}\text { Interval Persentase } \\
\text { Hasil Belajar }\end{array}$ & $\begin{array}{c}\text { Tingkat Hasil } \\
\text { Belajar }\end{array}$ & $\mathbf{f}$ & $\boldsymbol{\%}$ \\
\hline $90 \%-100 \%$ & Sangat Tinggi & 1 & 3 \\
\hline $80 \%-89 \%$ & Tinggi & 4 & 11 \\
\hline $65 \%-79 \%$ & Sedang & 13 & 35 \\
\hline $55 \%-64 \%$ & Rendah & 17 & 46 \\
\hline $0 \%-54 \%$ & Sangat Rendah & 2 & 5 \\
\hline \multicolumn{2}{|r|}{ Jumlah } & 37 & 100 \\
\hline
\end{tabular}

Nilai siswa siklus I, nilai terendah 40 dan nilai tertinggi 90, dengan rata-rata nilai 63. Pada tabel 2 di atas, dapat diketahui bahwa hasil belajar siklus I dari 37 siswa setelah dilakukan pembelajaran pada mata pelajaran IPS $\mathrm{D}=18 / 37 \times 100 \%=49 \%$ yang mencapai tingkat ketuntasan belajar $(\geq 65 \%)$ sedangkan siswa yang belum mencapai tingkat ketuntasan belajar sebanyak 19 siswa (51\%). Tingkat ketuntasan klasikal 49\%. Tabel 3 menunjukkan, dari 5 tingkat hasil belajar yang paling banyak siswa berada pada tingkat rendah yaitu sebanyak 17 siswa. Hal tersebut menunjukkan nilai siklus I siswa masih tergolong rendah dan siswa MIN Medan Petisah belum tuntas mempelajari materi pelajaran keragaman suku bangsa dan budaya yang ada di Indonesia pada mata pelajaran IPS. Oleh karena itu, perlunya dilakukan perbaikan dan memberikan tindakan pada tahap selanjutnya.

\section{Siklus II}

Berdasarkan hasil observasi terhadap aktivitas siswa yang dilakukan selama proses belajar pada siklus II memiliki 3 kategori yaitu, baik, cukup, dan kurang. Hasil observasi tersebut dapat dilihat pada tabel 4.

Tabel 4. Deskripsi Aktivitas Siswa Siklus II

\begin{tabular}{|l|l|c|}
\hline No & \multicolumn{1}{|c|}{ Aktivitas Siswa } & Kategori \\
\hline 1 & Berpartisipasi dalam pembelajaran & Baik \\
\hline 2 & Keseriusan siswa mengikuti pelajaran & Baik \\
\hline 3 & Suasana kelas pada saat PBM & Baik \\
\hline 4 & Keaktifan siswa dalam bertanya & Baik \\
\hline 5 & Mendengar dan memperhatikan guru & Baik \\
\hline 6 & Interaksi antara siswa & Cukup \\
\hline
\end{tabular}


Tiap kategori memiliki poin poin masing-masing. 6 komponen pilihan yang tertera dalam lembar observasi ada 5 poin untuk kategori baik dan 1 poin kategori cukup, dan 0 poin untuk kategori kurang. Hasil observasi tersebut menunjukkan bahwa kegiatan di dalam kelas pembelajaran IPS sudah mulai maksimal dan tergolong baik. Siswa sudah mulai serius dalam mengikuti proses pembelajaran dan suasana kelas juga sangat kondusif, serta siswa sangat bersemangat dalam proses pembelajaran di siklus II.

Pada akhir siklus II diberikan tes akhir. Dianggap berhasil apabila siswa mendapat nilai $\geq 65$. Persentase hasil belajar siswa pada tes akhir II dapat dilihat pada tabel 5.

Tabel 5. Pengelompokan Ketuntasan Hasil Belajar Siklus II

\begin{tabular}{|l|c|c|}
\hline \multicolumn{1}{|c|}{ Kategori } & f & \% \\
\hline Tuntas & 35 & 95 \\
\hline Tidak tuntas & 2 & 5 \\
\hline Jumlah & 37 & 100 \\
\hline
\end{tabular}

Tabel 6. Persentase dan Tingkat Hasil Belajar Siswa Siklus II

\begin{tabular}{|l|c|c|c|}
\hline $\begin{array}{c}\text { Interval Persentase } \\
\text { Hasil Belajar }\end{array}$ & $\begin{array}{c}\text { Tingkat Hasil } \\
\text { Belajar }\end{array}$ & $\mathbf{f}$ & $\%$ \\
\hline $90 \%-100 \%$ & Sangat Tinggi & 26 & 70 \\
\hline $80 \%-89 \%$ & Tinggi & 6 & 16 \\
\hline $65 \%-79 \%$ & Sedang & 3 & 8 \\
\hline $55 \%-64 \%$ & Rendah & 2 & 5 \\
\hline $0 \%-54 \%$ & Sangat Rendah & 0 & 0 \\
\hline & & 37 & 100 \\
\hline
\end{tabular}

Berdasarkan data hasil belajar siklus II yang diperoleh, nilai terendah 60 dan nilai tertinggi 100 dengan rata-rata 89. Pada tabel 5 diatas maka dapat diketahui bahwa nilai siklus II dari 37 siswa setelah dilakukan pembelajaran pada mata pelajaran IPS D = 35/37 x $100 \%=95 \%$ yang sudah mencapai tingkat ketuntasan belajar $(\geq 65)$, sedangkan 2 siswa $(5,40 \%)$ yang belum mencapai tingkat ketuntasan. Tingkat ketuntasan klasikal mencapai ketuntasan sebesar 95\%. Hal ini menunjukkan nilai siklus II siswa mengalami peningkatan dan tergolong tinggi. Dengan demikian maka dapat dikatakan bahwa hasil belajar siswa MIN Medan Petisah sudah mengalami ketuntasan dalam mempelajari materi pelajaran keragaman suku bangsa dan budaya yang ada di Indonesia. Pada mata pelajaran IPS.

Berdasarkan rekapitulasi nilai siswa pada siklus I dan siklus II, ada 36 siswa hasil belajanya meningkat dan hasil belajar 1 siswa tetap. Apabila hasil belajar tiap siswa pada siklus I dan siklus II dibandingkan, maka dapat dikatakan bahwa hasil belajar tiap siswa 
meningkat. Hasil peningkatan hasil belajar IPS siswa pada siklus I dan II dapat dilihat pada gambar 1.

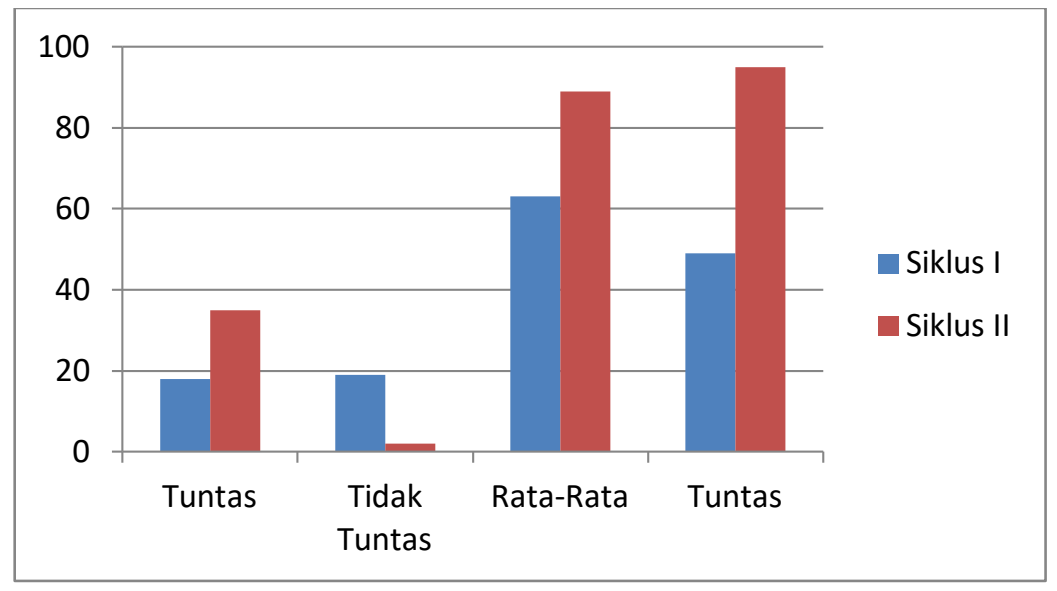

\section{Gambar 1. Hasil Belajar IPS Siswa Siklus I dan siklus II}

Adapun yang membedakan antara siklus I dan siklus II ini adalah terletak pada pengkolaborasian antara metode-metode yang digunakan, pada siklus I dalam proses pembelajaran peneliti menggunakan metode poster comment, setiap siswa bebas untuk mengomentari gambar yang telah diperlihatkan oleh guru, dan hasilnya adalah rata-rata 63 dengan ketuntasan klasikal 49\%, sedangkan pada siklus II peneliti menggunakan metode diskusi kelompok dan strategi index card matc, di mana siswa dibagi menjadi 6 kelompok untuk mencocokkan kartu yang berisi gambar-gambar, dan hasilnya adalah rata-rata 89 dengan ketuntasan klasikal 95\%.

Dengan demikian, maka dapat disimpulkan terjadi peningkatan hasil belajar siswa dalam belajar setelah diberikan pengajaran dan pemahaman materi IPS dengan menggunakan media gambar pada mata pelajaran IPS dikelas V MIN Medan Petisah. Peningkatan yang diperoleh sebesar $46 \%$.

\section{SIMPULAN}

Dalam proses pembelajaran guru menggunakan gambar-gambar yang berkaitan dengan materi IPS dan menarik perhatian siswa. Aktivitas belajar siswa meningkat dari siklus I ke siklus II. Penggunaan media gambar pada pembelajaran IPS dengan pokok bahasan keragaman suku bangsa dan budaya yang ada di Indonesia dapat meningkatkan hasil belajar siswa kelas V MIN Medan Petisah. 
Penggunaan Media Gambar Untuk Meninngkatkan Hasil Belajar ... -Dahniar Harahap

\section{DAFTAR PUSTAKA}

Abdurrahman, M. 2003. Pendidikan Bagi Anak Yang Kesulitan Belajar. Jakarta: Rineka Cipta. Ahmad, R. 1999. Media Instruktsional Edukarif. Jakarta: Rineka Cipta.

Arief, S. 1986. Media Pendidikan. Jakarta: Rajawali Pers.

Arsyad, A. 2011. Media Pembelajaran. Jakarta: Rajawali Pers.

Asrori, M. 2009. Penelitian Tindakan Kelas. Bandung: Wacana Prima.

Hamalik, 0. 2001. Proses Belajar Mengajar. Bandung: Bumi Aksara.

Nana, S. 2009. Penilaian Hasil Proses Belajar Mengajar. Bandung: Remaja Rosdakarya.

Rahadi, A. Media Pembelajaran. Jakarta: Dikjen Dikti Depdikbud, 2003

Ramadhan, S. 2010. Kamus Ilmiah Populer. Surabaya: Khazanah Media Ilmu.

Rayandra, A. 2011. Kreatif Mengembangkan Media Pembelajaran. Jakarta: Gaung Persada Press. 